Supporting Information

\title{
Designed three-in-one peptides with anchoring, antifouling and recognizing capabilities for highly sensitive and low- fouling electrochemical sensing in complex biological media
}

\author{
Zhen Song, Min Chen, Caifeng Ding, Xiliang Luo
}

Key Laboratory of Optic-electric Sensing and Analytical Chemistry for Life Science,

MOE; Shandong Key Laboratory of Biochemical Analysis; Key Laboratory of Analytical Chemistry for Life Science in Universities of Shandong; College of Chemistry and Molecular Engineering. Qingdao University of Science and Technology, Qingdao 266042, PR China.

*Corresponding author. Tel: + 86532 84022681; Fax: + 86532 84023927. E-mail: xiliangluo@qust.edu.cn 
List of Supporting Information:

S-1. Static water contact angles

S-2. Investigation of the designed peptide

S-3. ATR-FTIR spectroscopy

S-4. Structure of the designed multifunctional peptide

S-5. DPV response to two different probes

S-6. Optimization of sensing conditions

S-7. Antifouling ability of different surfaces in human serum solution

S-8. Antifouling ability of different surfaces in FBS solution

S-9. Cell adhesion investigation

S-10. Stability of the biosensor

S-11. Reusability of the biosensor

S-12. Tables S1, Tables S2 


\section{S-1. Static water contact angles}

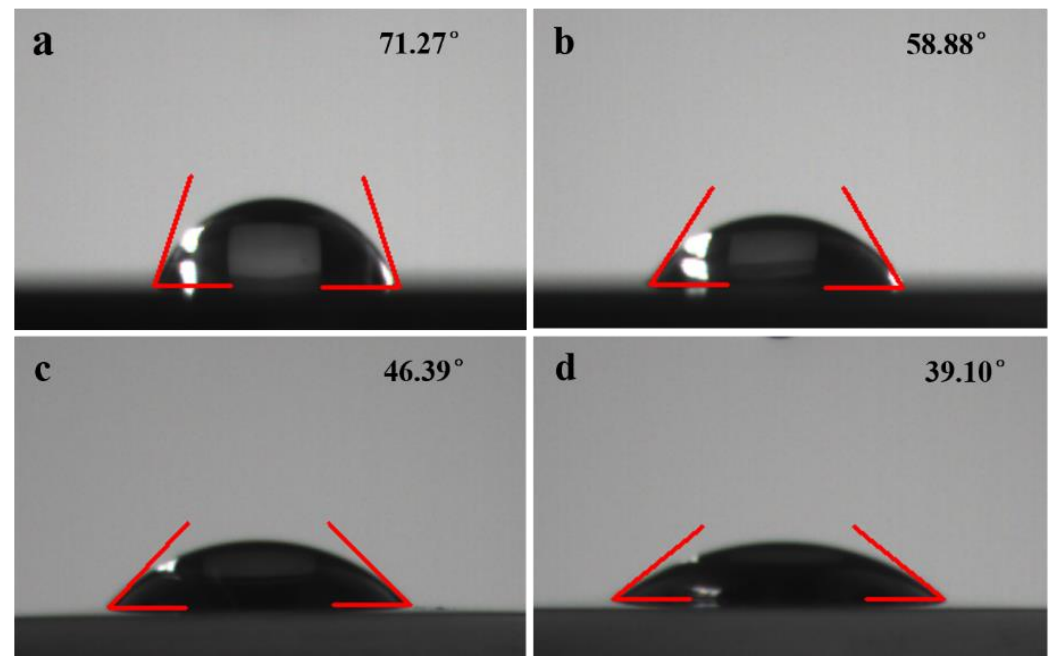

Figure S1. Contact angle characterization of the PEDOT-citrate film within phosphate buffer solutions of various $\mathrm{pH}(\mathrm{a}, \mathrm{pH}$ 1; $\mathrm{b}, \mathrm{pH} 4$; $\mathrm{c}, \mathrm{pH} 7$; $\mathrm{d}, \mathrm{pH} 11)$.

\section{S-2. Investigation of the designed peptide}

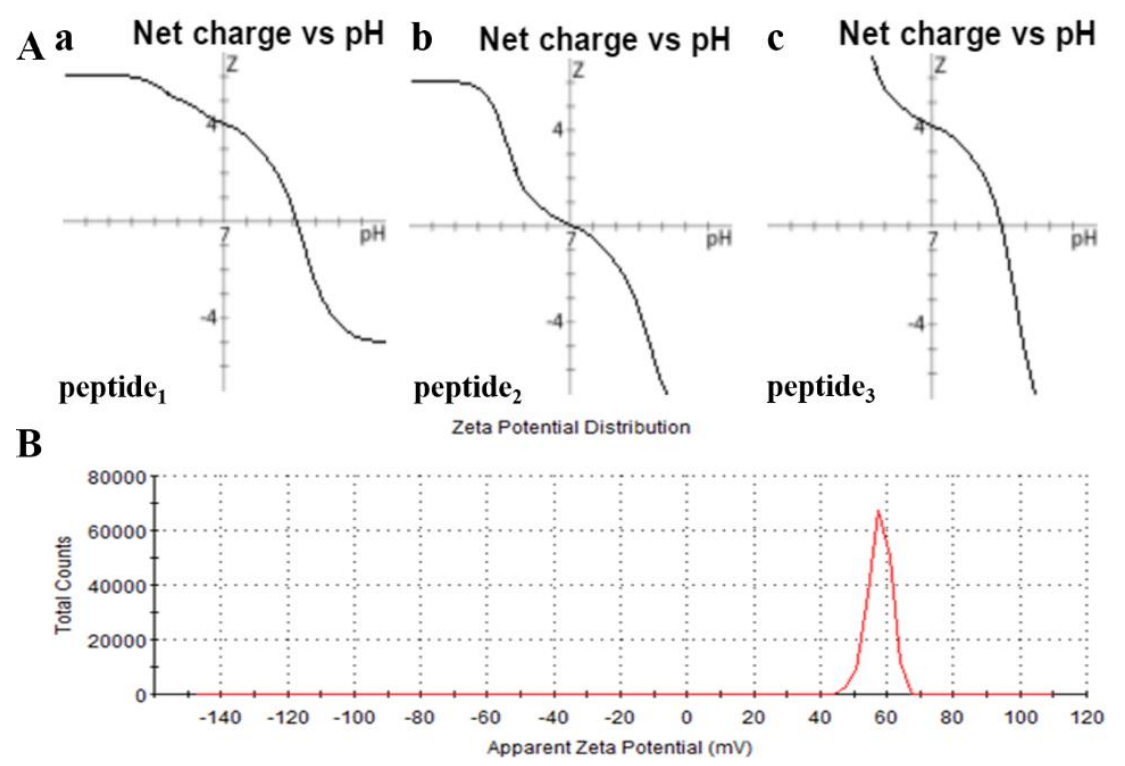

Figure S2. (A) The relationship between the net charge of the peptide and pH. (B) Zeta potential of the designed multifunctional peptide (peptide $)_{3}$. Peptide ${ }_{1}$, YVEYHLCRAKAKAKAK; peptide, $_{2}$ YVEYHLCREKEKEKEK; peptide, YVEYHLCREKEKEKEKAKAKAKAK. 


\section{S-3. ATR-FTIR spectroscopy}

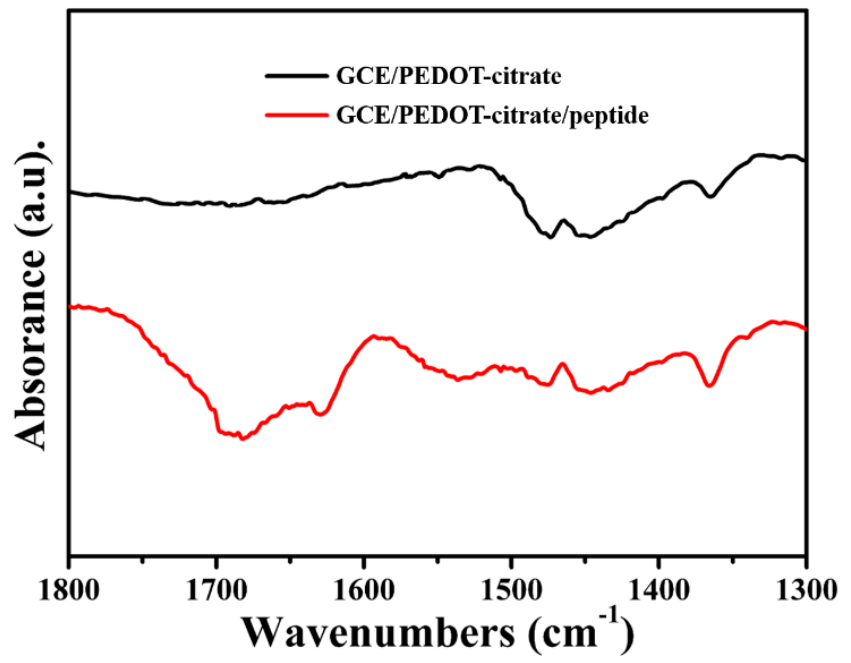

Figure S3. ATR-FTIR spectra of the PEDOT-citrate and PEDOT-citrate/peptide surfaces.

\section{S-4. Structure of the designed multifunctional peptide}

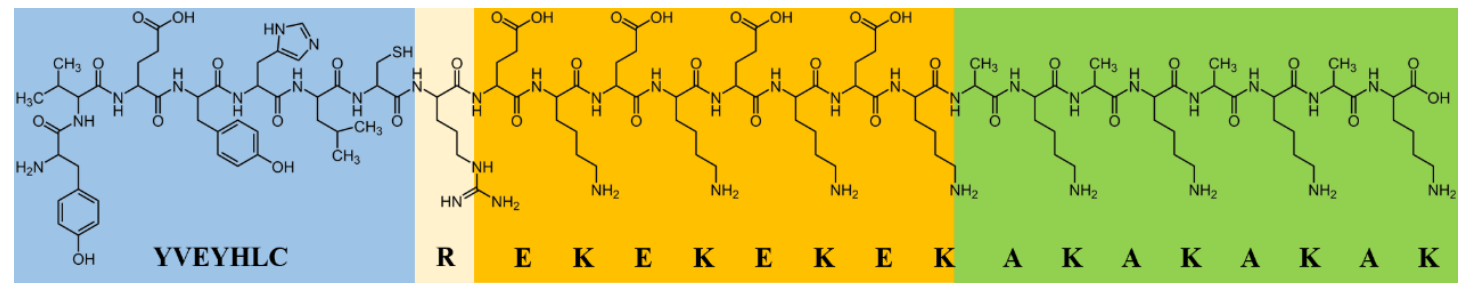

Figure S4. Structure of the designed multifunctional peptide with sequence of YVEYHLCREKEKEKEKAKAKAKAK used in present work. 


\section{S-5. DPV response to two different probes}


Figure S5. DPV curves were recorded at different modified electrodes in PBS (10 mM, pH 7.4) containing $0.1 \mathrm{M} \mathrm{KCl}, 5.0 \mathrm{mM}\left[\mathrm{Fe}(\mathrm{CN})_{6}\right]^{3-/ 4-}(\mathrm{A})$ and $\left[\mathrm{Ru}\left(\mathrm{NH}_{3}\right)_{6}\right]^{3+}(\mathrm{B}) . \mathrm{a}$, bare GCE; b, GCE/PEDOT-citrate; c, GCE/PEDOT-citrate/peptide; d, GCE/PEDOTcitrate/peptide/APN.

\section{S-6. Optimization of sensing conditions}
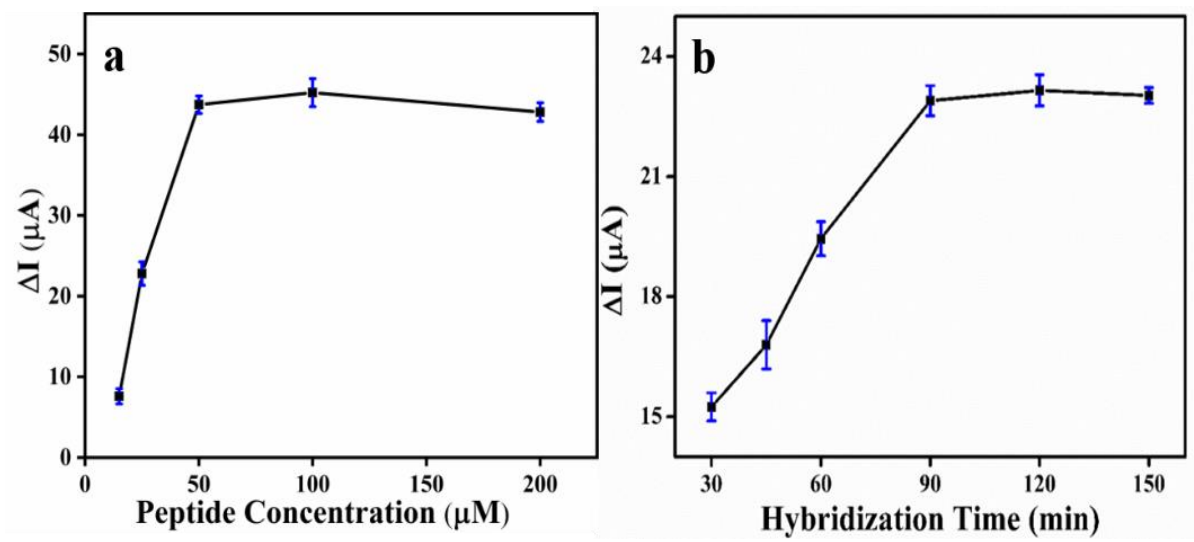

Figure S6. Optimization of the peptide concentration (a), APN incubation time (b). Error bars represent the standard deviations of three repeated determinations $(n=3)$. 


\section{S-7. Antifouling ability of different surfaces in human serum solution}
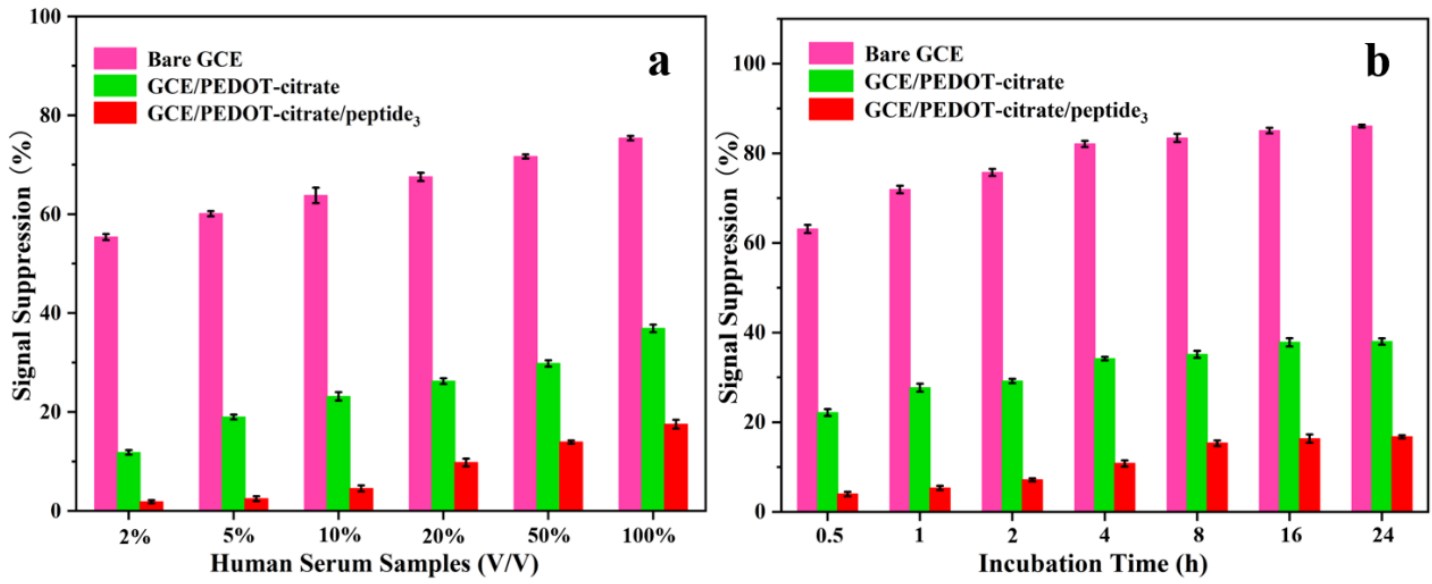

Figure S7. The antifouling performance of the bare, PEDOT-citrate, PEDOTcitrate/peptide 3 modified GCE in different concentration of human serum solution (V/V) (a), and longtime antifouling performance against $24 \mathrm{~h}$ incubation in $10 \%$ human serum solution (b).

\section{S-8. Antifouling ability of different surfaces in FBS solution}



Figure S8. Comparative antifouling performance of the bare, PEDOT-citrate, PEDOTcitrate/peptide $_{\mathrm{x}}$ modified GCE in FBS samples (V/V). Ppeptide ${ }_{1}$, YVEYHLCRAKAKAKAK; peptide $_{2}$, YVEYHLCREKEKEKEK; peptide $_{3}$, YVEYHLCREKEKEKEKAKAKAKAK. 


\section{S-9. Cell adhesion investigation}


Figure S9. Fluorescence microscopy images of PEDOT-citrate/peptide 3 modified electrodes after incubation in $10^{4}$ cells $\cdot \mathrm{mL}^{-1}$ of HepG2 (a) and HeLa (b) cells.

\section{S-10. Stability of the biosensor}
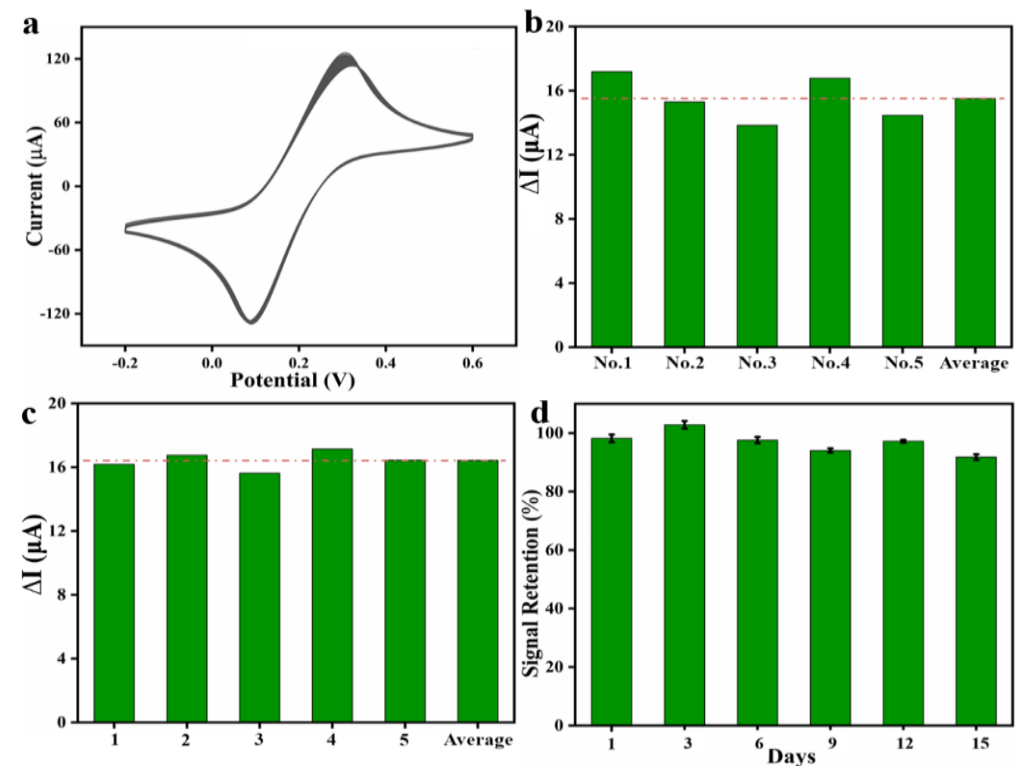

Figure S10. (a) Stab i l ity of the PEDOT-citrate/peptide 3 biosensor with CV at a scan of $0.10 \mathrm{~V} \cdot \mathrm{s}^{-1}$. (b) The DPV response changes $[\Delta \mathrm{I}]$ of five different biosensors for the detection of $1 \mu \mathrm{g} \cdot \mathrm{mL}^{-1} \mathrm{APN}$, and (c) the detection of $1 \mu \mathrm{g} \cdot \mathrm{mL}^{-1} \mathrm{APN}$ with the same biosensors. $\left(\Delta \mathrm{I}=\mathrm{I}_{\text {target}}-\mathrm{I}_{0}\right)(\mathrm{d})$ Stability of the prepared biosensor stored at PBS (10 $\mathrm{mM}, \mathrm{pH}$ 7.4). The CV and DPV were record in PBS (10 mM, pH 7.4) containing 5.0 $\mathrm{mM}\left[\mathrm{Fe}(\mathrm{CN})_{6}\right]^{3-/ 4-}$ and $0.1 \mathrm{M} \mathrm{KCl}$.

\section{S-11. Reusability of the biosensor}






Figure S11. The reusability of the modified electrode for APN detection with the concentration of $5 \mu \mathrm{g} \cdot \mathrm{mL}^{-1}$. Error bars represent the standard deviations of three repeated determinations $(n=3)$.

\section{S-12. Tables S1, Tables S2}

Table S1. Static water contact angle values of bare, PEDOT-citrate modified and PEDOT-citrate/peptide 3 modified GCE.

\begin{tabular}{cccc}
\hline & \multicolumn{3}{c}{${\text { Contact angle }\left({ }^{\circ}\right)}^{\text {Test points }}$} \\
\cline { 2 - 4 } & Bare GCE & $\begin{array}{c}\text { GCE/PEDOT- } \\
\text { citrate }\end{array}$ & $\begin{array}{c}\text { GCE/PEDOT- } \\
\text { citrate/peptide }\end{array}$ \\
\hline 1 & 63.44 & 46.39 & 29.56 \\
2 & 63.02 & 47.04 & 29.21 \\
3 & 62.57 & 46.76 & 28.95 \\
Average & $63.01 \pm 0.4$ & $46.73 \pm 0.3$ & $29.24 \pm 0.3$ \\
\hline
\end{tabular}

Table S2. Comparison of various detection methods for APN assay.

Analytical Linear range $\left(\mu \mathrm{g} \cdot \mathrm{mL}^{-1}\right) \quad$ Detection limit References




\begin{tabular}{cccc}
\hline methods & & \\
\hline Colorimetric & $5-15$ & $0.42 \mu \mathrm{g} \cdot \mathrm{mL}^{-1}$ & 1 \\
Fluorescence & $0-6 \times 10^{-3}$ & $33 \mathrm{pg} \cdot \mathrm{mL}^{-1}$ & 2 \\
Fluorescence & $0.01-0.5$ & $0.8 \mathrm{ng} \cdot \mathrm{mL}^{-1}$ & 3 \\
Fluorescence & $0-0.1$ & $0.25 \mathrm{ng} \cdot \mathrm{mL}^{-1}$ & 4 \\
Fluorescence & Not mentioned & $0.30 \mathrm{mU}$ & 5 \\
Electrochemistry & $0.001-15$ & $0.4 \mathrm{ng} \cdot \mathrm{mL}^{-1}$ & This work \\
\hline
\end{tabular}

\section{References}

(1) Mao, X. X.; Li, Y. F.; Han, P.; Wang, X. H.; Yang, S. Q; Zhang, F.; Gong, X. Q; Cao, $\mathrm{Y}$. One-pot and one-step colorimetric detection of aminopeptidase $\mathrm{N}$ activity based on gold nanoparticles-based supramolecular structure. Sens. Actuators, B 2018, 267, 336-341.

(2) He, X. Y.; Xu, Y. H.; Shi, W.; Ma, H. M. Ultrasensitive Detection of Aminopeptidase N Activity in Urine and Cells with a Ratiometric Fluorescence Probe. Anal. Chem. 2017, 89 (5), 3217-3221.

(3) He, X. Y.; Hu, Y. M.; Shi, W.; Li, X. H.; Ma, H. M. Design, synthesis and application of a near-infrared fluorescent probe for in vivo imaging of aminopeptidase N. Chem. Commun. (Cambridge, U. K.) 2017, 53 (68), 9438-9441.

(4) Li, H. D.; Li, Y. Q.; Yao, Q. C.; Fan, J. L.; Sun, W.; Long, S.; Shao, K.; Du, J. J.; Wang, J. Y.; Peng, X. J. In situ imaging of aminopeptidase $\mathrm{N}$ activity in hepatocellular carcinoma: a migration model for tumour using an activatable twophoton NIR fluorescent probe. Chem. Sci. 2019, 10 (6), 1619-1625.

(5) Chen, L. Z.; Sun, W.; Li, W. H.; Li, J.; Du, L. P.; Xu, W. F.; Fang, H.; Li, M. Y. The first ratiometric fluorescent probe for aminopeptidase N. Anal. Methods 2012, 4 (9), 2661-2663. 